\title{
A preliminary assessment of singlet oxygen scavenging, cytotoxic and genotoxic properties of Geranium macrorrhizum extracts`
}

\author{
Petras Rimantas Venskutonis ${ }^{1}$, Veronika Dedonytė², Juozas Lažutka², Gražina Slapšytè2, \\ Audronè Marozienè ${ }^{3}$, Aušra Nemeikaitè-Čèniené ${ }^{4}$, Narimantas Čènas ${ }^{3}$ and Giedrius Miliauskas ${ }^{1}$
}

\begin{abstract}
Strong radical-scavenging activity of Geranium macrorrhizum extracts isolated by using various solvent systems has been reported previously. This study aimed at expanding the knowledge on the bioactivities of antioxidatively active G. macrorrhizum butanol fraction, which was isolated from ethanolic extract (EB), and water fraction, which was isolated from water extract (WW) by measuring their singlet oxygen scavenging properties, as well as preliminary assessment of cytotoxicity and genotoxicity toward mammalian cells. The cytotoxicity (necrosis induction) of the extracts in bovine leukemia virus-transformed lamb kidney fibroblasts (line FLK) was partly prevented by antioxidants and stimulated by the prooxidant BCNU ( $N, N^{\prime}$-bis(2-chloroethyl)- $N$-nitrosourea). This indicates that the cytotoxicity of G. macrorrhizum extracts is at least partly attributed to their prooxidant action, presumably due to the formation of quinoidal products of their (auto)oxidation. The latter was evidenced by the nature of the peroxidase-catalyzed oxidation products, which supported DT-diaphorase-catalyzed oxidation of NADPH and participated in conjugation reactions with reduced glutathione. The genotoxic properties were studied using chromosome aberration (CA) and sister chromatid exchange (SCE) tests in human lymphocytes in vitro and Drosophila melanogaster somatic mutation and recombination test (SMART) in vivo. In the CA test, only the highest doses of both fractions significantly increased chromosome aberration frequency. In the SCE test, both fractions induced SCEs in a clear dose-dependent manner. G. macrorrhizum extracts were not genotoxic in the SMART test in vivo. Our data indicate that in spite of the possible beneficial (antioxidant) effects of Geranium extracts, the possibilities of their use as ingredients of functional foods and/or food supplements should be further examined due to their cytoand genotoxic effects resulting mainly from the action of quercetin-derived components abundant in the extracts.
\end{abstract}

Keywords: Geranium macrorrhizum, polyphenols, cytotoxicity, genotoxicity

Received: 27 October, 2009; revised: 14 November, 2009; accepted: 08 February, 2010; available on-line: 06 May, 2010

\section{INTRODUCTION}

Aromatic and medicinal plants are a good source of bioactive compounds which may be valuable ingredients for various applications, including pharmaceuticals, func- tional foods and food supplements. With the advent of modern analytical and bioactivity assessment techniques studies of plant-derived natural preparations and purified compounds has expanded substantially; however, considering the vast biodiversity of the plant kingdom and the numerous factors affecting the production of secondary metabolites in plants this area of research is still not sufficiently explored. Thus, our previous studies of aromatic and medicinal plants grown in Lithuania by using various methods resulted in the evaluation of antioxidative properties of some less investigated plants (Dapkevicius et al., 1998; Weel et al., 1999; Bandonienè et al., 2000; Povilaitytè \& Venskutonis, 2000) and identification of new natural antioxidants (Dapkevicius et al., 2002; Pukalskas et al., 2002; Miliauskas et al., 2004a; 2005). Extracts of Geranium macrorrbizum were shown to possess powerful radical scavenging capacity (Miliauskas et al., 2004b) and antioxidant activity, which were due to the presence of the identified polyphenolic components (Miliauskas et al., 2004c). The antioxidative properties of G. macrorrbizum extracts added as natural antioxidants were further evaluated in Dutch-style fermented sausages (Miliauskas et al., 2007). G. macrorrbizum is a grassy perennial plant with long roots, which is used for the production of essential oil containing mainly the sesquiterpene garmacrone. The plant is known to be rich in tannins and its extracts have been reported to possess a broad spectrum of antimicrobial activities. In addition it was declared to have strong hypotensive, astringent activity, as well as cardiotonic and sedative properties (BateSmith, 1981; Ivancheva et al., 1992).

The bioactivities of plant extracts are partially associated with the presence of various polyphenolic compounds, which may scavenge free radicals, thus acting as primary antioxidants as well as quenching and reacting with singlet oxygen $\left({ }^{1} \mathrm{O}_{2}\right)$ (Tournaire et al., 1993; Darmanian et al., 1998; Bensasson et al., 1999). However, apart from their beneficial properties, polyphenols may be tox-

e-mail: rimas.venskutonis@ktu.lt

* Presented at the COST B-35 Work Group 4 Open Workshop "Natural and synthetic antioxidants", September 25-26, 2009, Rzeszów, Poland.

Abbreviations: $\mathrm{AlPcS}_{4}, \mathrm{Al}$-phthalocyanine tetrasulphonate; $\mathrm{BCNU}$, $N, N^{\prime}$-bis(2-chloroethyl)- $N$-nitrosourea; $\mathrm{Cl}_{50}$ compound concentration doubling the photohemolysis time of erythrocytes; $\mathrm{CL}_{50}$, compound concentration causing $50 \%$ cell death; CA, chromosome aberration; DMSO, dimethyl sulfoxide; EB, ethanol/butanol fraction; $\mathrm{NQO1}$, $\mathrm{NAD}(\mathrm{P}) \mathrm{H}$ : quinone oxidoreductase; $\mathrm{POD}$, peroxidase; $\mathrm{RI}$, refractive index; ROS, reactive oxygen species; $S C E$, sister chromatid exchange; SMART, somatic mutation and recombination test; WW, water/water fraction. 
ic in mammalian cells among other modes of their action by exerting oxidative stress-type cytotoxicity. This is attributed to the polyphenol autoxidation in cell growth media with the production of extracellular $\mathrm{H}_{2} \mathrm{O}_{2}$ (Nakagawa et al., 2004, and references therein), the intracellular generation of reactive oxygen species (Galati \& O'Brien, 2004, and references therein), and the depletion of intracellular reduced glutathione (GSH) and other reduced thiols by the quinone/quinomethide-type (auto)oxidation products of polyphenols (Boersma et al., 2000).

Plant extracts are very complex mixtures often containing toxic as well as antimutagenic compounds. Therefore, studies on their "latent" toxicities such as teratogenesis, carcinogenesis and mutagenesis are of particular relevance. The genotoxic effects of plant extracts have been studied over the years and it was shown that a great number of plants that are used as food ingredients or in traditional medicine possess mutagenic properties (Lazutka et al., 2001; Cardoso et al., 2006; DecigaCampos et al., 2007; Verschaeve \& van Staden, 2008). Considering the growing use of plant extracts, genotoxicity testing and identification of genotoxic compounds could help to increase their safety.

The objectives of the present study were to evaluate the singlet oxygen scavenging, cytotoxicity and genotoxic activities of selected fractions of $G$. macrorrhizum extracts. For the latter purpose we used chromosome aberration and sister chromatid exchange tests in human lymphocytes in vitro and Drosophila melanogaster wing spot somatic mutation and recombination test (SMART) in vivo.

\section{MATERIALS AND METHODS}

Preparation of extracts and their fractions. Dried plant material of G. macrorrbizum was obtained from the Kaunas Botanical Garden of Vytautas Magnus University (Lithuania). The extracts and their fractions were prepared from $100 \mathrm{~g}$ of dry ground mass by step-wise extraction as described previously (Miliauskas et al., 2004c). Briefly, herb was extracted with $2 \times 500 \mathrm{ml}$ of tert-butyl methyl ether (TBME) at room temperature for $2 \times 12 \mathrm{~h}$ under constant stirring with a magnetic stirrer. The TBME extract was filtered through a medium porosity filter paper and the solvent was evaporated in a rotary evaporator. The residue of plant material remaining after extraction with TBME was re-extracted under the same conditions with ethanol $(96 \%, \mathrm{v} / \mathrm{v})$ and finally with $\mathrm{H}_{2} \mathrm{O}$. The extracts obtained with $\mathrm{EtOH}$ and $\mathrm{H}_{2} \mathrm{O}$ were further partitioned between water and 1-butanol resulting in ethanol/butanol (EB), ethanol/water (EW), water/butanol (WB) and water/water (WW) fractions. The EW and WW fractions were freeze-dried. Seven phenolic compounds, namely gallic acid, ellagic acid, 4-galloyl quinic acid, the flavonoid quercetin and three of its glycosides, quercetin-3- $\beta$-glucopyranoside, quercetin-3$\beta$-galactopyranoside and quercetin-4'- $\beta$-glucopyranoside were isolated and identified in the various fractions (Miliauskas et al., 2004c).

Enzymatic reactions. Rat liver $\mathrm{NAD}(\mathrm{P}) \mathrm{H}$ : quinone oxidoreductase (DT-diaphorase, NQO1, EC 1.6.99.2) was prepared as described elsewhere (Prochaska, 1988), while horseradish peroxidase (POD, EC 1.11.1.7) was obtained from Sigma. The enzyme concentrations were determined spectrophotometrically according to $\varepsilon_{460}=11$ $\mathrm{mM}^{-1} \cdot \mathrm{cm}^{-1}$ (NQO1), and $\varepsilon_{402}=102 \mathrm{mM}^{-1} \cdot \mathrm{cm}^{-1}$ (POD). All other reagents were obtained from Sigma and used as received. Enzymatic reactions carried out in $0.1 \mathrm{M}$
K-phosphate ( $\mathrm{pH} 7.0)$ with $1 \mathrm{mM}$ EDTA at $25^{\circ} \mathrm{C}$ were studied spectrophotometrically using a Hitachi-557 UVVIS spectrophotometer. To characterize the spectral changes during the POD-catalyzed oxidation, the spectra of $10-50 \mu \mathrm{g} / \mathrm{ml}$ of extracts were recorded at 250-700 $\mathrm{nm}$ before and after the incubation with $0.1 \mu \mathrm{M}$ POD and $100-300 \mu \mathrm{M} \mathrm{H}_{2} \mathrm{O}_{2}$ for $5 \mathrm{~min}$. In separate experiments, $5.0 \mathrm{mM}$ GSH was added at the end of the reaction. The activity of the extract oxidation product(s) in supporting NQO1-catalyzed NADPH oxidation was studied as follows: after the oxidation of extracts by POD $+\mathrm{H}_{2} \mathrm{O}_{2}$, the excess $\mathrm{H}_{2} \mathrm{O}_{2}$ was decomposed by $50 \mathrm{U} / \mathrm{mg}$ catalase. Subsequently, $100 \mu \mathrm{M}$ NADPH and $20 \mathrm{nM}$ of NQO1 were introduced into the reaction mixture, and the NADPH oxidation rate was determined according to $\Delta \varepsilon_{340}=6.2 \mathrm{mM}^{-1} \mathrm{~cm}^{-1}$. In control samples in the absence of NQO1 the oxidation of NADPH by the extract oxidation product(s) did not take place.

Mammalian cell cytotoxicity studies. Bovine leukemia virus-transformed lamb kidney fibroblasts (line FLK) were grown and maintained in Eagle's medium supplemented with $10 \%$ fetal bovine serum at $37^{\circ} \mathrm{C}$ as described previously (Nemeikaitè-Čenienè et al., 2005, and references cited therein). Cells $\left(2.5 \times 10^{4} / \mathrm{ml}\right.$, final volume, $5 \mathrm{ml}$ ) were seeded on $18 \mathrm{~mm} \times 18 \mathrm{~mm}$ glass slides in $5 \mathrm{ml}$ flasks in the presence or in the absence of extracts and additional compounds and were grown for $24 \mathrm{~h}$. The extracts and additional compounds were dissolved in DMSO, and 5-10 $\mu$ l of DMSO solution was added into the cell growth medium. In control experiments, this amount of DMSO did not affect cell viability. Further, the slides were rinsed with phosphate-buffered saline, and stained with Trypan Blue. The viable and nonviable (necrotic Trypan Blue-accumulating) cells on the slides were counted under a light microscope.

Erythrocyte photohemolysis protection studies. Freshly prepared suspension of human erythrocytes (Vilnius Blood Transfusion Centre) was stored in $0.01 \mathrm{M}$ K-phosphate with $0.137 \mathrm{M} \mathrm{NaCl}, 2.7 \mathrm{mM} \mathrm{KCl}$, $10 \mathrm{mM}$ glucose, and $1 \mathrm{mM}$ EDTA as described previously (Maroziené et al., 2000). For photolysis experiments, erythrocytes were diluted with the same solution to $2.5-2.6 \times 10^{6} / \mathrm{ml}$. Aftewards, $10 \mu \mathrm{M}$ Al-phthalocyanine tetrasulphonate $\left(\mathrm{Al}-\mathrm{PcS}_{4}\right.$, Porphyrin Products, Logan, UT, USA) and extract solution were added to a stirred suspension of erythrocytes in the dark, $30 \mathrm{~min}$ prior to irradiation. The irradiation was performed at $25^{\circ} \mathrm{C}$ under continuous stirring, in a $1.0 \mathrm{~cm}$ inner diameter glass cell. The light source was a $250 \mathrm{~W}$ tungsten lamp with a cut-off filter $(\lambda>590 \mathrm{~nm})$ and a fluence rate of 25 $\mathrm{W} / \mathrm{m}^{2}$. During continuous irradiation aliquots of erythrocytes $(0.1 \mathrm{ml})$ were taken and diluted 20 times. The degree of their lysis was measured according to the decrease in their apparent absorbance at $740 \mathrm{~nm}$ caused by cell disruption (Sorata et al., 1988). Typically, the erythrocyte lysis was characterized by a lag-phase of 40-60 min, which was defined as the intercept of the tangent to the turning point of the lysis curve with the time axis. The efficiency of compounds in the protection of erythrocytes from photohemolysis was expressed as the concentration giving a 2 -fold increase in the lag-phase $\left(\mathrm{cI}_{50}\right)$. It was calculated from lag-phase $v s$. extract concentration plots. Complete hemolysis was obtained by addition of $40 \mu \mathrm{g} / \mathrm{ml}$ digitonin to erythrocytes.

Cytogenetic test in human lymphocytes in vitro. Whole peripheral blood from healthy volunteer was incubated at $37^{\circ} \mathrm{C}$ for $72 \mathrm{~h}$ in Hepes-buffered RPMI 1640 medium supplemented with $12 \%$ heat-inactivated new- 
born calf serum, $7.8 \mu \mathrm{g} / \mathrm{ml}$ phytohemagglutinin $\mathrm{P}, 50$ $\mu \mathrm{g} / \mathrm{ml}$ gentamycin, $10 \mu \mathrm{g} / \mathrm{ml}$ 5-bromo-2'-deoxyuridine. All reagents used for the cell culture were purchased from Sigma. Treatment with plant extracts was carried out $48 \mathrm{~h}$ after culture initiation and lasted for $24 \mathrm{~h}$. As whole blood cultures display many properties common with the liver microsomal cytochrome P450 system (Starke \& Mieyal, 1989), no external metabolising enzymes were added. Test solutions were prepared in RPMI 1640 medium (WW) or dissolved in ethanol (EB) and then diluted with RPMI 1640 medium to the desired concentration. Working solutions of extracts were made just before treatment. Two parallel cultures were used for each concentration of plant extracts tested. Ethanol at a final concentration of $7.5 \mu \mathrm{l} / \mathrm{ml}$ was used as a solvent control for the EB fraction. Ethanol concentration in the experimental series did not exceed this concentration. Two cultures were left untreated and served as a blank control. The cultures were exposed to colchicine at a final concentration of $0.6 \mu \mathrm{g} / \mathrm{ml}$ for the last $3 \mathrm{~h}$ of incubation. The cells were harvested, hypotonically swollen in $0.075 \mathrm{M} \mathrm{KCl}$ and fixed in methanol/acetic acid $(3: 1, \mathrm{v} / \mathrm{v})$. Air-dried slides were differentially stained by fluorescence plus Giemsa technique as described previously (Lazutka, 1991). Briefly, the slides were stained for $10 \mathrm{~min}$ with $10 \mu \mathrm{g} / \mathrm{ml}$ of Hoechst 33258 dye (dissolved in $0.07 \mathrm{M}$ Soerensen's buffer, $\mathrm{pH}$ 6.8). Then the slides were rinsed, wetted with citrate buffer ( $\mathrm{pH}$ 8.5), covered with cover slips and exposed to UV light (400 W mercury lamp at a distance of $15 \mathrm{~cm}$ ) for 6-7 $\mathrm{min}$. The slides were then rinsed and stained for 3-4 min with 5\% Giemsa. Cytogenetic analysis was performed on coded slides. No less than 100 first-mitotic division metaphases per culture were analysed for chromosome aberrations, and no less than 50 second-division metaphases for sister chromatid exchanges. Aberrations were scored as individual types, but for convenience they were grouped as chromatid breaks (ctb), chromatid exchanges (cte), chromosome breaks (csb) and chromosome exchanges (cse).

Cell replicative kinetics was determined by means of replicative index $\left(R I=\left[M_{1}+2 M_{2}+3 M_{3}\right] / N\right.$, where $M_{1}$. $\mathrm{M}_{2} . \mathrm{M}_{3}$ are the numbers of cells that had undergone one, two or three cycles of replication, and $\mathrm{N}$ is the total number of cells scored). Three hundred cells were scored to determine RI.

Somatic mutation and recombination test (SMART) in Drosophila melanogaster in vivo. The basic procedures for the $D$. melanogaster somatic mutation and recombination test (SMART) were performed according to Graf et al. (1984) and Graf and van Schaik (1992). Offspring from a cross of ORR/ORR; $\mathrm{fr}^{3} / \mathrm{In}$ (3LR) TM3, ri pp sep l(3)89Aa bx $x^{34 e}$ e $B d^{5}$ females with mwh/mwh males were used for mutation analysis (both strains kindly provided by Dr H. Frei, Zurich, Switzerland). The ORR strain has chromosomes 1 and 2 from a DDT-resistant Oregon strain characterized by constitutively over-expressed CYP450 genes. The CYP450 enzymes play the main role in the bioactivation of xenobiotics, as well as natural products including phytochemicals (van Iersel et al., 1999). Thus, the use of this high-bioactivation strain of $D$. melanogaster facilitates the detection of promutagens of numerous classes of compounds. The markers mwh (multiple wing hairs) and $f r^{3}$ (misshapen, flare-like hairs) are recessive wing-hair mutations located on the third chromosome at genetic map positions 0.3 and 38.8, respectively.

Eggs from the crosses were collected over $10 \mathrm{~h}$ periods. Progeny were raised on Instant Drosophila Medium
(No. D7670, Sigma) at $25^{\circ} \mathrm{C}$. Two schedules of larvae treatment were applied. Firstly, the crossed flies were permitted to lay eggs for $10 \mathrm{~h}$ in vials containing medium prepared with the test solution. Thus, the exposure duration was about $120 \mathrm{~h}$ (i.e., the period from fly egg till case-worm). According to the second schedule, the $72 \pm 5$ h-old larvae were exposed to plant extracts by adding test solution to the surface of the medium and were fed on this medium for the rest of their development, during approx. $48 \mathrm{~h}$. The test solutions were prepared in distilled water (WW fraction) or dissolved in ethanol (EB fraction) and then diluted with distilled water to the desired concentration, with the final ethanol concentration $5 \%(\mathrm{v} / \mathrm{v})$. The solutions were always prepared immediately before use. Solvent controls were included in all treatments. Trans-heterozygous ( $m w h \mathrm{fr}^{+} / \mathrm{mwh}^{+} \mathrm{fr} \mathrm{r}^{3}$ ) flies were collected and stored in $70 \%$ ethanol. The wings of adult flies were mounted on glass slides in Faure's solution, coded and scored under a magnification of $400 \times$ (Nikon E200) for the presence of single ( $m w h$ or $f r^{3}$ phenotype) or twin (adjacent $m w h$ and $f r^{3}$ clones) spots. The spots were recorded according to standard procedures (Graf et al., 1984). No less than 40 wings were analysed per each experimental point.

Statistical analysis. Statistical analyses were performed using InStat V2.02 (GraphPad Software. CA. USA) statistical package. Statistical tests were chosen according to the nature of the data analysed. $X^{2}$-test with Yate's correction was used to estimate the induction of chromosome aberrations and somatic mutations. A oneway analysis of variance (ANOVA) and the Student's two-sided $t$-test were used for the evaluation of SCE occurrence, and z-test for RI analysis. $P<0.05$ was considered as the level of significance.

\section{RESULTS AND DISCUSSION}

\section{Protective effects of G. macrorrhizum extracts against ${ }^{1} \mathrm{O}_{2}$-mediated photohemolysis of erythrocytes}

In order to extend previously reported data on the antioxidant properties of G. macrorrbizum extracts (Miliauskas et al., 2004c), we analyzed their capacity to neutralize the damaging action of singlet oxygen $\left({ }^{1} \mathrm{O}_{2}\right)$, using human erythrocyte photosensitized lysis by Al-phthalocyanine tetrasulphonate $\left(\mathrm{Al}-\mathrm{PcS}_{4}\right)($ Maroziene et al., 2000). Earlier studies showing the absence of photohemolysis protection by catalase and superoxide dismutase, and protective effects of azide, a specific quencher of ${ }^{1} \mathrm{O}_{2}$, have demonstrated that ${ }^{1} \mathrm{O}_{2}$ plays a major role in the erythrocyte lysis (Maroziene et al., 2000). For G. macrorrhizum extracts, the $\mathrm{cI}_{50}$ values calculated from the data in Table 1 were equal to $\geq 300 \mu \mathrm{g} / \mathrm{ml}$ (EB fraction) and $\geq 380 \mu \mathrm{g} / \mathrm{ml}$ (WW fraction). Among the polyphenols

Table 1. Protective effects of G. macrorrhizum EB and WW fractions against $\mathrm{Al}^{-} \mathrm{PcS}_{4}$-induced photohemolysis of erythrocytes $n=3, P<0.02$ for $(2-4)$ vs. (1).

\begin{tabular}{llcc}
\hline No. & Additions $(\mu \mathrm{g} / \mathrm{ml})$ & \multicolumn{2}{c}{ lag-period $(\mathrm{min})$} \\
\hline & & a) EB & b) WW \\
1. & None & $45 \pm 6.0$ & $51 \pm 7.0$ \\
2. & 100 & $60 \pm 8.0$ & $62 \pm 5.0$ \\
3. & 200 & $72 \pm 6.0$ & $74 \pm 6.0$ \\
4. & 300 & $88 \pm 8.0$ & $89 \pm 7.0$ \\
\hline
\end{tabular}




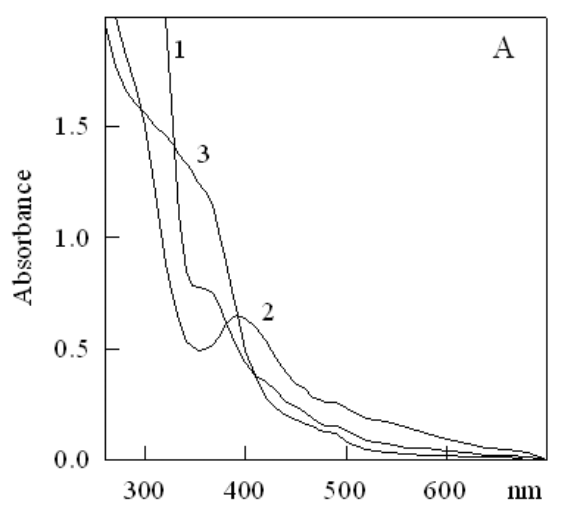

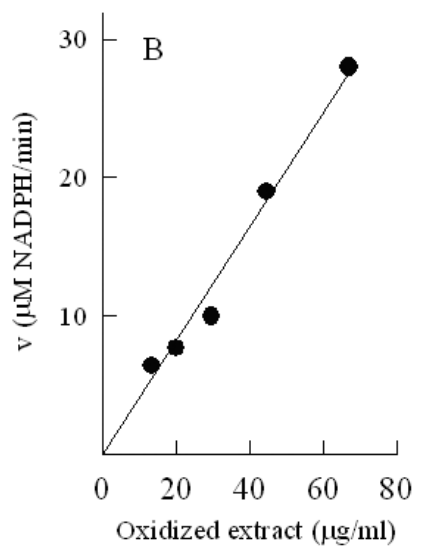

Figure 1 . The activity of G. macrorrhizum extracts towards redox enzymes.

(A) Absorbance of extract $(50 \mu \mathrm{g} / \mathrm{ml})$ before (1) and after addition of $1.0 \mu \mathrm{M}$ peroxidase and $100 \mu \mathrm{M} \mathrm{H}_{2} \mathrm{O}_{2}$ (2), and after subsequent addition of $5 \mathrm{mM}$ GSH (3); (B) oxidation of NADPH $(100 \mu \mathrm{M})$ by $0.02 \mu \mathrm{M}$ flavoenzyme DT-diaphorase $(\mathrm{NAD}(\mathrm{P}) \mathrm{H}$ :quinone oxidoreductase. identified in G. macrorrbizum extracts, quercetin possessed a $\mathrm{cI}_{50}=170 \pm 30 \mu \mathrm{M}$, which corresponds to $51 \pm 9.0 \mu \mathrm{g} /$ $\mathrm{ml}$, whereas gallic acid was a much less effective protecting agent $\left(\mathrm{cI}_{50} \geq 2.0 \mathrm{mM}\right.$, or $\geq 340 \mu \mathrm{g} / \mathrm{ml}$ (Marozienè et al., 2000)). Thus, one may expect that quercetin but not gallic acid plays a major role in the protective effects of G. macrorrbizum extracts against ${ }^{1} \mathrm{O}_{2}$. This also may be valid for their glycoside derivatives, because the presence of a carbohydrate moiety decreases the lipophilicity of polyphenolic compounds (Nemeikaitè-Čenienè et al., 2005) and in turn decreases their protection efficiency against the photosensitized erythrocyte lysis (Marozienè et al., 2000).

\section{Prooxidant mammalian cell cytotoxicity of G. macrorrhizum extracts}

As one of the cytotoxicity mechanisms of polyphenols is associated with the formation of their prooxidant (auto)oxidation products of quinoidal structure, first we examined the possibility of formation of quinoidal oxidation products in G. macrorrbizum extracts. The oxidation of $G$. macrorrbizum EB fraction by a model system, $\mathrm{H}_{2} \mathrm{O}_{2}$ and peroxidase (POD) (Metodiewa et al., 1999), leads to a disappearance of the absorbance shoulder at $360 \mathrm{~nm}$ and to the formation of a new absorbance peak at $400 \mathrm{~nm}$ (Fig. 1A). The subsequent addition of GSH leads to the formation of new product(s) possessing an absorbance shoulder at $350 \mathrm{~nm}$ (Fig. 1A). This shows that polyphenolic components of $G$. macrorrbizum extracts may be oxidized into quinone-type compounds which may react with GSH forming GS-substituted hydroquinones (Boersma et al., 2000; Galati \& O’Brien, 2004). The formation of quinone-type compounds during the POD-catalyzed oxidation of polyphenolic components of $G$. macrorrbizum extracts is confirmed by the dose-dependent effect of the oxidised extract on DTdiaphorase $(\mathrm{NAD}(\mathrm{P}) \mathrm{H}$ : quinone oxidoreductase, NQO1, EC 1.6.99.1)-catalyzed NADPH oxidation (Fig. 1B). This reaction is almost completely inhibited by $20 \mu \mathrm{M}$ dicumarol, a specific inhibitor of NQO1. This definitely shows that quinoidal compounds may be formed during the (auto)oxidation of polyphenolic components of $G$. macrorrbizum extracts.

In the course of preliminary studies of the cytotoxicity (necrosis induction) by $G$. macrorrbizum extracts we used a bovine leukemia virus-transformed lamb embryo kidney fibroblasts culture (line FLK), which serves as a reference base in our investigation of prooxidant compounds (Nemeikaitè-Čènienè et al., 2005, and references therein). In this case, 98-99\% of cells adhering to the glass sides did not accumulate Trypan Blue, i.e., they were viable. The $\mathrm{cL}_{50}$ (compound concentration causing $50 \%$ cell death) was equal to $112 \pm 15 \mu \mathrm{g} / \mathrm{ml}$ (EB fraction) or $63 \pm 7.5 \mu \mathrm{g} / \mathrm{ml}$ (WW fraction). For comparison, in FLK cells the $\mathrm{cL}_{50}$ of quercetin was equal to $42 \pm 5.4$ $\mu \mathrm{g} / \mathrm{ml}(140 \pm 18 \mu \mathrm{M})$, and that for gallic acid was equal to $128 \pm 12 \mu \mathrm{g} / \mathrm{ml}(750 \pm 70 \mu \mathrm{M})$ (Nemeikaitè-Č́nienè et al., 2005). Again, this shows that the cytotoxicity of $G$. macrorrhizum extracts may be mainly attributed to the action of quercetin and its derivatives, but not to those of gallic acid. The prooxidant nature of the cytotoxicity of G. macrorrbizum EB fraction is further confirmed by the data in Table 2, which show that the extract cytotoxicity was prevented by the antioxidant $N, N$-diphenyl- $p$-phenylene diamine (DPPD) and by the Fe-ion chelator desferrioxamine, the latter preventing the Fenton reaction, but was stimulated by BCNU (N,N'-bis(2-chloroethyl)$N$-nitrosourea) which acts as a prooxidant through inactivating the antioxidant enzyme glutathione reductase (EC 1.6.4.3) (Ollinger \& Brunmark, 1991; NemeikaiteCéniene et al., 2005). Considering other modes of the cytotoxicity of polyphenolic plant extracts, it is worth noting that the induction of apoptosis, a programmed cell death, in several cell lines by the isolated polyhydroxybenzenes and flavonoids was caused by ROS formation, also being partly prevented by DPPD and desferrioxamine (Nemeikaité-Čènienè et al., 2009, and references therein). This also points to the prooxidant character of their apoptosis induction. However, further studies should be performed in this direction taking into account parallel apoptosis induction mechanisms of polyphenols, which apparently do not involve the formation of reactive oxygen species (Hsu et al., 2007; Chien et al., 2009).

\section{Genotoxicity of G. macrorrhizum extracts}

Genotoxicity in human lymphocytes in vitro was assessed using two endpoints - chromosome aberrations and sister chromatid exchanges. Analysis of chromosome aberrations is widely accepted as a test for clastogenicity. Although the exact mechanism that leads to an increased exchange of segments between sister chromatids is still not known, sister chromatid exchanges are successfully adopted as a test for genotoxicity. Both tests are used in genotoxicity assessment of plant-derived chemicals (Stopper et al., 2005). The EB as well as WW fractions of G. macrorrbizum extract induced sister chromatid exchanges in a clear dose-dependent manner (Table 3). The dose-response relationships may be described by linear equations: $\mathrm{Y}=8.24+0.08 \mathrm{X}\left(\mathrm{r}^{2}=0.96\right)$ for $\mathrm{EB}$ fraction and $\mathrm{Y}=10.09160+0.07 \mathrm{X}\left(\mathrm{r}^{2}=0.98\right)$ for the WW fraction, where $\mathrm{Y}$ is the number of sister chromatid exchanges per cell, $\mathrm{X}$ is the concentration of the extract $(\mu \mathrm{g} / \mathrm{ml})$. Treat- 
Table 2. The cytotoxicity of G. macrorrhizum EB extract.

Effects of antioxidant $N, N^{\prime}$-diphenyl-p-phenylene diamine (DPPD), Fe-ion chelator desferrioxamine, and potentiating effect of prooxidant alkylating agent $N, N^{\prime}$-bis (2-chloroethyl)- $N$-nitrosourea (BCNU)

\begin{tabular}{ll}
\hline Additives & $\begin{array}{l}\text { Cell viability }(\%) \\
(n=3-4, P<0.02)\end{array}$ \\
\hline G. macrorrhizum $\mathrm{EB}, 110 \mu \mathrm{g} / \mathrm{ml}$ & $49.2 \pm 2.5$ \\
Extract + DPPD $(3.0 \mu \mathrm{M})$ & $70.3 \pm 3.5$ \\
Extract + desferrioxamine $(300 \mu \mathrm{M})$ & $72.8 \pm 4.9$ \\
Extract + BCNU $(20 \mu \mathrm{M})$ & $29.2 \pm 3.9$
\end{tabular}

DMSO, 5-10 $\mu \mathrm{L}$ in $5 \mathrm{ml}$ growth media (negative control) decreased cell viability by $<1 \%$.

ment with extracts did not inhibit cell replicative kinetics. In the chromosome aberration test, the WW fraction caused a significant increase of chromosome aberrations at the highest concentration $(200 \mu \mathrm{g} / \mathrm{ml})$ only (Table 4). The EB fraction of $G$. macrorrbizum extract was the most clastogenic at a concentration of $150 \mu \mathrm{g} / \mathrm{ml}$ (more than eightfold increase over ethanol control), while at a higher concentration the number of aberrant cells decreased (Table 4). The prevalent type of induced aberrations in the case of both WW and EB fractions was chromatid breaks. Interestingly, that genotoxicity profile of the EB fraction in human lymphocytes in vitro was very similar to that one reported for another plant-derived complex mixture, essential oil from peppermint herb (Lazutka et al., 2001).

Pooled data of the wing spot analysis are reported in Table 5. It should be noted that there were very few spots, predominantly single small ones (not shown). Water controls showed background frequencies of 16.3$20.4 \%$ wings with spots and $0.18-0.20$ total spots per wing. These values are within the range previously reported in the literature ( 0.16 to 0.60 total spots per fly) (Tellez et al., 2007; Castro et al., 2008). The frequencies of wings with spots and total spots in ethanol controls did not significantly differ from those in the water controls. No statistically significant difference between respective controls and different concentrations of the test solutions was found after $48 \mathrm{~h}$ or $120 \mathrm{~h}$ treatment. A statistically significant increase in the total number of spots was observed only among the flies treated with $1 \%$ WW fraction with exposure duration of $120 \mathrm{~h}$, compared with the spot frequency in the water control.

The data presented in this study concern a genotoxic assessment of two fractions of $G$. macrorrbizum extract. The use of in vitro and in vivo assays was decisive in or-

Table 3. Effects of different fractions of G. macrorrhizum extract on the frequency of sister chromatid exchanges (SCE) and replication index (RI) in human lymphocyte cultures

\begin{tabular}{|c|c|c|c|c|}
\hline \multirow{2}{*}{ Concentration of test solution $(\mu \mathrm{g} / \mathrm{ml})$} & \multicolumn{2}{|c|}{ Water/water (WW) fraction } & \multicolumn{2}{|c|}{ Ethanol/butanol (EB) fraction } \\
\hline & SCE/cell \pm S.E.M. & $\mathrm{RI} \pm$ S.E.M & SCE/cell \pm S.E.M. & $\mathrm{RI} \pm$ S.E.M \\
\hline Blank & $8.76 \pm 0.49$ & $2.47 \pm 0.05$ & & \\
\hline Ethanol $(7.5 \mu \mathrm{l} / \mathrm{ml})$ & & & $9.34 \pm 0.41$ & $2.15 \pm 0.06$ \\
\hline 25 & $11.68 \pm 0.65$ & $2.31 \pm 0.05$ & $10.84 \pm 0.55$ & $2.59 \pm 0.04$ \\
\hline 50 & $14.18 \pm 0.62^{a}$ & $2.44 \pm 0.05$ & $10.58 \pm 0.49$ & $2.33 \pm 0.05$ \\
\hline 100 & $17.46 \pm 1.02^{a}$ & $2.36 \pm 0.05$ & $14.86 \pm 0.79$ & $2.37 \pm 0.05$ \\
\hline 150 & $21.42 \pm 1.00^{a}$ & $2.36 \pm 0.05$ & $20.60 \pm 1.19 a$ & $2.27 \pm 0.05$ \\
\hline 200 & $23.04 \pm 0.88^{a}$ & $2.46 \pm 0.03$ & $24.42 \pm 1.08^{a}$ & $2.23 \pm 0.05$ \\
\hline
\end{tabular}

a $P<0.05$ as compared to appropriate solvent control

Table 4. Induction of chromosome aberrations in human lymphocytes by different fractions of Geranium macrorrhizum extract

\begin{tabular}{|c|c|c|c|c|c|c|c|}
\hline \multirow{2}{*}{ Treatment } & \multirow{2}{*}{ Concentration $(\mu \mathrm{g} / \mathrm{ml})$} & \multirow{2}{*}{$\begin{array}{l}\text { Number of meta- } \\
\text { phases analysed }\end{array}$} & \multirow{2}{*}{ 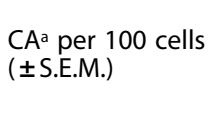 } & \multicolumn{4}{|c|}{ Number of aberrations ${ }^{a}$} \\
\hline & & & & $\mathrm{ctb}$ & cte & $\mathrm{csb}$ & cse \\
\hline Blank & 0 & 100 & $1.0 \pm 0.99$ & 1 & 0 & 0 & 0 \\
\hline Ethanol & 7.5 & 100 & $2.0 \pm 1.4$ & 2 & 0 & 0 & 0 \\
\hline \multirow{5}{*}{$\begin{array}{l}\text { Water/water (WW) } \\
\text { fraction }\end{array}$} & 25 & 100 & $3.0 \pm 1.7$ & 3 & 0 & 0 & 0 \\
\hline & 50 & 100 & $4.0 \pm 1.9$ & 3 & 0 & 1 & 0 \\
\hline & 100 & 100 & $1.0 \pm 0.99$ & 1 & 0 & 0 & 0 \\
\hline & 150 & 100 & $2.0 \pm 1.4$ & 2 & 0 & 0 & 0 \\
\hline & 200 & 100 & $8.0 \pm 2.7^{b}$ & 7 & 0 & 1 & 0 \\
\hline \multirow{5}{*}{$\begin{array}{l}\text { Ethanol/butanol (EB) } \\
\text { fraction }\end{array}$} & 25 & 100 & $7.0 \pm 2.5$ & 7 & 0 & 0 & 0 \\
\hline & 50 & 100 & $6.0 \pm 2.4$ & 2 & 0 & 2 & 2 \\
\hline & 100 & 100 & $4.0 \pm 1.9$ & 2 & 1 & 1 & 0 \\
\hline & 150 & 100 & $17.0 \pm 3.8^{b}$ & 16 & 0 & 1 & 0 \\
\hline & 200 & 100 & $7.0 \pm 2.5$ & 7 & 0 & 0 & 0 \\
\hline
\end{tabular}

a CA, chromosome abberation; ctb, chromatid breaks; cte, chromatid exchanges; csb, chromosome breaks; cse, chromosome exchanges; ${ }^{\circ}<0.05$ as compared to appropriate solvent control. 
Table 5. Results of Drosophila wing spot test after treatment with different fractions of G. macrorrhizum extracts

\begin{tabular}{|c|c|c|c|c|c|c|c|c|}
\hline \multirow{3}{*}{$\begin{array}{l}\text { Concentration } \\
\text { of test solution } \\
(\%)\end{array}$} & \multicolumn{4}{|c|}{ Water/water (WW) fraction } & \multicolumn{4}{|c|}{ Ethanol/butanol (EB) fraction } \\
\hline & \multicolumn{2}{|c|}{$\begin{array}{l}\text { Exposure duration } \\
48 \mathrm{~h}\end{array}$} & \multicolumn{2}{|c|}{$\begin{array}{l}\text { Exposure duration } \\
120 \mathrm{~h}\end{array}$} & \multicolumn{2}{|c|}{$\begin{array}{l}\text { Exposure duration } \\
48 \mathrm{~h}\end{array}$} & \multicolumn{2}{|c|}{$\begin{array}{l}\text { Exposure duration } \\
120 \mathrm{~h}\end{array}$} \\
\hline & $\begin{array}{l}\text { Wings } \\
\text { with spots } \\
\text { (\% } \% \text { S.E.M.) }\end{array}$ & $\begin{array}{l}\text { Spots } \\
\text { per wing } \\
(\mathrm{m} \pm \text { S.E.M.) }\end{array}$ & $\begin{array}{l}\text { Wings } \\
\text { with spots } \\
\text { (\% } \% \text { S.E.M.) }\end{array}$ & $\begin{array}{l}\text { Spots } \\
\text { per wing } \\
(\mathrm{m} \pm \text { S.E.M.) }\end{array}$ & $\begin{array}{l}\text { Wings } \\
\text { with spots } \\
(\% \pm \text { S.E.M.) }\end{array}$ & $\begin{array}{l}\text { Spots } \\
\text { per wing } \\
\text { (m } m \text { S.E.M.) }\end{array}$ & $\begin{array}{l}\text { Wings } \\
\text { with spots } \\
\text { (\% } \% \text { S.E.M.) }\end{array}$ & $\begin{array}{l}\text { Spots } \\
\text { per wing } \\
(\mathrm{m} \pm \text { S.E.M.) }\end{array}$ \\
\hline Water & $20.4 \pm 6.1$ & $0.20 \pm 0.06$ & $16.3 \pm 5.3$ & $0.18 \pm 0.05$ & $20.4 \pm 6.1$ & $0.20 \pm 0.06$ & $16.3 \pm 5.3$ & $0.18 \pm 0.05$ \\
\hline Ethanol (5\%) & $23.9 \pm 6.3$ & $0.24 \pm 0.06$ & $21.2 \pm 5.9$ & $0.21 \pm 0.06$ & $23.9 \pm 6.3$ & $0.24 \pm 0.06$ & $21.2 \pm 5.9$ & $0.21 \pm 0.06$ \\
\hline 0.1 & $22.4 \pm 6.0$ & $0.27 \pm 0.06$ & $20.4 \pm 5.7$ & $0.20 \pm 0.06$ & $22.4 \pm 6.0$ & $0.23 \pm 0.06$ & $16.3 \pm 5.3$ & $0.16 \pm 0.05$ \\
\hline 0.5 & $26.5 \pm 6.3$ & $0.35 \pm 0.07$ & $22.4 \pm 5.9$ & $0.22 \pm 0.06$ & $17.0 \pm 5.5$ & $0.17 \pm 0.05$ & $28.6 \pm 6.4$ & $0.33 \pm 0.07$ \\
\hline 1 & $28.6 \pm 6.4$ & $0.35 \pm 0.07$ & $31.3 \pm 6.7$ & $0.35 \pm 0.07^{a}$ & $15.5 \pm 5.4$ & $0.15 \pm 0.05$ & $22.4 \pm 6.0$ & $0.23 \pm 0.06$ \\
\hline
\end{tabular}

a $P<0.05$ as compared to appropriate control

der to cover different types of genotoxic damage. Only a slight (though significant at the highest concentrations) increase of chromosome aberrations was observed in human lymphocytes in vitro. However, both EB and WNW fractions turned out to be potent inducers of SCEs. The dose-response relationships were linear for both fractions. The G. macrorrbizum extract is a complex mixture containing different phytochemical components. As it was mentioned above, gallic, ellagic and 4-galloyl quinic acids, quercetin and its glycosides have been identified in G. macrorrbizum extracts. These substances possess strong antioxidative activity (Miliauskas et al., 2004c). However, previous studies have shown quercetin to have a dual effect. Low doses of quercetin have been shown to protect against oxidative injuries, while higher doses induced DNA damage, gene mutations and chromosome aberrations (Skibola \& Smith, 2000; Stopper et al., 2005). Our results suggest that the genotoxicity of $G$. macrorrbizum extract in human lymphocytes in vitro can be attributed to a pro-oxidant effect of quercetin. This proposition is substantiated by the findings of other researchers. The mutagenicity of four commercial ethanolic plant extracts (Tinctura Alchemillae, Extractum Crataegi, Extractum Myrtilli, Tinctura Hyperici) was attributed to the presence of quercetin (Schimmer et al., 1988). Moreover, the mutagenic potential of the extracts was shown to correlate well with their quercetin content.

The genotoxicity of G. macrorrbizum extract in vivo was evaluated using the somatic mutation and recombination test (SMART) in D. melanogaster, employing flies with an increased cytochrome P450-dependent biotransformation capacity. This so-called high bioactivation cross (HB cross) makes the wing spot test more sensitive for the detection of promutagens and procarcinogens (Graf \& van Schaik, 1992). The SMART data showed that at the concentrations tested the extracts did not induce somatic mutation or recombination in the $D$. melanogaster crosses. Taking into account that the SMART assay records different genotoxic events, either mutation (point mutations, specific types of chromosome aberrations, etc.) or mitotic recombination, the negative results obtained in this work indicate that G. macrorrbizum extracts are not mutagenic in Drosophila.

Conclusions. It seems that the protective effects of G. macrorrbizum extracts against ${ }^{1} \mathrm{O}_{2}$ and their prooxidant toxicity are mainly determined by the action of quercetin and its derivatives. The data also show that the extracts from G. macrorrbizum are genotoxic in cytogenetic tests in vitro, though they revealed no genotoxic activity when investigated in the $D$. melanogaster assay in vivo. Our results suggest that further investigations are necessary to determine whether the G. macrorrbizum extract or its components can be used without hazard to human health.

\section{Acknowledgements}

Part of this study was performed in the framework of COST Action B35.

Supported by the Lithuanian State Science and Studies Foundation, grant no. C03

\section{REFERENCES}

Bandonienè D, Pukalskas A, Venskutonis PR, Gruzdienè D (2000) Preliminary screening of antioxidant activity of some plant extracts in rapeseed oil. Food Res Int 33: 785-791.

Bate-Smith EC (1981) Astringent tannins of the leaves of Geranium species. Phytochemistry 20: 211-216.

Bensasson RV, Jossang A, Zahir A, Bodo B, Land EJ (1999) Redox regulation of tumor cell toxicity by flavones from Lethedon tannaensis. Free Rad Biol Med 27: 95-99.

Boersma MG, Vervoort J, Szymusiak H, Lemanska K, Tyrakowska B, Čenas N, Segura-Aguilar J, Rietjens IMCM (2000) Regioselectivity and reversibility of the glutathione conjugation of quercetin quinone methide. Chem Res Toxicol 13: 185-191.

Cardoso CRP, de Syllos Colus IM, Bernardi CC, Sannomiya M, Vilegas W, Varanda EA (2006) Mutagenic activity promoted by amentoflavone and methanolic extract of Byrsonima crassa Niedenzu. Toxicology 225: 55-63.

Castro AJS, Grisolia CK, de Araujo BC, Dias CD, Dutra ES, Nepomuceno JC (2008) Recombinogenic effects of the aqueous extract of pulp from pequit fruit (Caryocar brasilense) on somatic cells of Drosophila melanogaster. Genet Mol Res 7: 1375-1383.

Chien S-Y, Wu Y-C, Chung J-G, Yang J-S, Lu H-F, Tsou M-F, Wood WG, Kuo S-J, Chen D-R (2009) Quercetin-induced apoptosis acts through mitochondrial- and caspase-3-dependent pathways in human breast cancer MDA-MB-231 cells. Human Exptl Toxicol 28: 493-503.

Dapkevičius A, Venskutonis R, van Beek TA, Linssen JPH (1998) Antioxidant activity of extracts obtained by different isolation procedures from some aromatic herbs grown in Lithuania. J Sci Food Agric 77: 140-146.

Dapkevicius A, van Beek TA, Lelyveld GP, van Veldhuizen A, de Groot A, Linssen JPH, Venskutonis R (2002) Isolation and structure elucidation of radical scavengers from Thymus vulgaris leaves. $J$ Nat Prod 65: 892-896.

Darmanian AP, Jenks WJ, Jardon P (1998) Charge-transfer quenching of singlet oxygen $\mathrm{O}_{2}\left({ }^{1} \Delta_{\mathrm{g}}\right)$ by amines and aromatic hydrocarbons. $J$ Phys Chem A 102: 7420-7426.

Deciga-Campos M, Rivero-Cruz I, Arriaga-Alba M, Castaneda-Corral G, Angeles-Lopez GE, Navarrete A, Mata R (2007) Acute toxicity and mutagenic activity of Mexican plants used in traditional medicine. I Ethnopharmacol 110: 334-342.

Galati G, O’Brien PJ (2004) Potential toxicity of flavonoids and other dietary phenolics: significance for their prevention and anticancer properties. Free Rad Biol Med 37: 287-303.

Graf U, van Schaik N (1992) Improved high bioactivation cross for the wing somatic mutation and recombination test in Drosophila melanogaster. Mutat Res 271: 59-67. 
Graf U, Wurgler FE, Katz AJ, Frei H, Juon H, Hall CB, Kale PG (1984). Somatic mutation and recombination test in Drosophila melanogaster. Environ Mutagen 6: 153-188.

Hsu C-L, Lo W-H, Yen G-C (2007) Gallic acid induces apoptosis in 3T3-L1 pre-adipocytes via a Fas- and mitochondrial-mediated pathway. J Agric Food Chem 55: 7359-7365.

Ivancheva S, Manolova N, Serkedjeva J, Dimov V, Ivanovska N (1992) Polyphenols from Bulgarian medicinal plants with anti-infectious activity. In Plant Polyphenols: Synthesis, Properties, Significance. Hemingway RW, Laks PE, eds, pp 717-728. Kluwer Academic/Plenum Publishers, Hardbound.

Lazutka JR (1991) Replication index in cultured human lymphocytes: methods for the statistical analysis and possible role in genetic toxicology. Environ Mol Mutagen 17: 188-195.

Lazutka JR, Mierauskienė J, Slapšyte G, Dedonytè V (2001) Genotoxicity of dill (Anethum graveolens L.), peppermint (Mentha piperita L.) and pine (Pinus sylvestris L.) essential oils in human lymphocytes and Drosophila melanogaster. Food Chem Toxicol 39: 485-492.

Marozienè A, Kliukienė R, Šarlauskas J, Čènas N (2000) Inhibition of phthalocyanine-sensitized photohemolysis of human erythrocytes by polyphenolic antioxidants: description of quantitative structure-activity relationships. Cancer Lett 157: 39-44.

Metodiewa D, Jaiswal AK, Čènas N, Sergediené E, Segura-Aguilar J (1999) Quercetin may act as a cytotoxic prooxidant after its metabolic activation to semiquinone and quinone product. Free Rad Biol Med 26: 107-116.

Miliauskas G, van Beek TA, Venskutonis PR, Linssen JPH, de Waard P, Sudholter EJ (2004a) Antioxidant activity of Potentilla fruticosa. J Sci Food Agric 84: 1997-2009.

Miliauskas G, Venskutonis PR, van Beek TA (2004b) Screening of radical scavenging activity of some medicinal and aromatic plant extracts. Food Chem 85: 231-237.

Miliauskas G, van Beek TA, Venskutonis PR, Linssen JPH, de Waard $P(2004 c)$ Antioxidative activity of Geranium macrorrbizum. Eur Food Res Technol 218: 253-261.

Miliauskas G, van Beek TA, de Waard P, Venskutonis RP, Sudholter EJR (2005) Identification of radical scavenging compounds in Rhaponticum carthamoides by means of LC-DAD-SPE-NMR. J Nat Prod 68: 168-172.

Miliauskas G, Mulder E, Linssen JPH, Jacques H, van Beek TA, Venskutonis PR (2007) Evaluation of antioxidative properties of Geranium macrorrbizum and Potentilla fruticosa extracts in Dutch style fermented sausages. Meat Sci 77: 703-708.

Nakagawa H, Hasumi K, Woo J-T, Nagai K, Wachi M (2004) Generation of hydrogen peroxide primarily contributes to the induction of $\mathrm{Fe}(\mathrm{II})$-dependent apoptosis in Jurkat cells by (-)-epigallocatechin gallate. Carcinogenesis 25: 1567-1574.

Nemeikaite-Č̉niené A, Imbrasaitė A, Sergediené E, Čènas N (2005) Quantitative structure-activity relationships in prooxidant cytotox- icity of polyphenols: role of potential of phenoxyl radical/phenol redox couple. Arch Biochem Biophys 441: 182-190.

Nemeikaitè-Ċènienè A, Marozienè A, Vidžiūnaitè R, Čènas N (2009) Prooxidant cytotoxicity, apoptosis induction, and protective effects of polyphenolic antioxidants. Chem Technol 3: 12-15.

Ollinger K, Brunmark A (1991) Effect of hydroxy substituent on 1,4-naphthoquinone toxicity to rat hepatocytes. J Biol Chem 266: 21496-21503.

Povilaityte V, Venskutonis PR (2000) Investigation of antioxidative activity of purple peril (Perilla frutescens L.), Moldavian dragonhead (Dracocephalum moldavica L.) and Roman chamomile (Anthemis nobilis L.) extracts in rapeseed oil. J Am Oil Chem Soc 77: 951-956.

Prochaska HJ (1988) Purification and crystallization of rat liver NAD (P) H: (quinone-acceptor) oxidoreductase by cibacron blue affinity chromatography: identification of a new and potent inhibitor. Arch Biochem Biophys 267: 529-538.

Pukalskas A, van Beek TA, Venskutonis RP, Linssen JPH, van Veldhuizen A, de Groot A (2002) Identification of radical scavengers in sweet grass (Hierocbloe odorata). J Agric Food Chem 50: 2914-2919.

Schimmer O, Hafele F, Kruger A (1988) The mutagenic potencies of plant extracts containing quercetin in Salmonella typhimurium TA98 and TA100. Mutat Res 206: 201-208.

Skibola CF, Smith MT (2000) Potential health impacts of excessive flavonoid intake. Free Radic Biol Med 29: 375-383.

Sorata Y, Takahama U, Kimura M (1988) Cooperation of quercetin with ascorbate in the protection of photosensitized lysis of human erythrocytes in the presence of hematoporphyrin. Photochem Photobiol 48: 195-199.

Stopper H, Schmitt E, Kobrasa K (2005) Genotoxicity of phytoestrogens. Mutat Res 574: 139-155.

Tellez MGO, Rodriguez HB, Olivares GQ, Sortibran ANC, Cetto AA, Rodriguez-Arnaiz R (2007) A phytotherapeutic extract of Equisetum myriochaetum is not genotoxic either in the in vivo wing somatic test of Drosophila or in the in vitro human micronucleus test. J Ethnopharmacol 111: 182-189.

Tournaire C, Croux S, Maurette M-T, Beck I, Hocquaux M, Braun AM, Oliveros E (1993) Antioxidant activity of flavonoids: efficiency of singlet oxygen $\left({ }^{1} \Delta_{\mathrm{g}}\right)$ quenching. J Photochem Photobiol B 19: 205212.

Van Iersel ML, Verhagen H, van Bladeren PJ (1999) The role of biotransformation in dietary (anti)carcinogenesis. Mutat Res 443: 259270.

Verschaeve L, van Staden J (2008) Mutagenic and antimutagenic properties of extracts from South African traditional medicinal plants. $J$ Ethnopharmacol 119: 575-587.

Weel KGC, Venskutonis PR, Pukalskas A, Gruzdienė D, Linssen JPH (1999) Antioxidant activity of horehound (Marrubium vulgare L.) grown in Lithuania. Fett/Lipid 101: 395-400. 